\title{
A Method of Computer-aided Modular Fixture Design, Part 2: Designing the Fixture under NC Manufacturing System
}

Zhun Wang

Anhui Polytechnic University, China. E-mail: CADCAM_246@126.com

This paper presents a new computer-aided method for modular-fixture design, in which the key point is building the fixture on the concept of NC Manufacturing System (NMS). In this paper, an approach of creation for a NMS is proposed, first to extract or setup the feature model of worktable of NC machine tool in any CAD system. Base on the worktable, the algorithm of computer-aided modular fixture design (CMFD) is then presented; the PostNC verification to check the performance of modular fixture in NC machining is introduced at the last section of the paper. This method could help engineers to develop and employ an error-free modular fixture during the complex NC-manufacturing production.

Keywords: NMS, Bridge Joint (BJ), Worktable-based Design of Modular Fixture, Post-NC Verification

\section{References}

[1] IAIN BOYLE, YIMING RONG, DAVID C. BROWN (2011). A review and analysis of current computer-aided fixture design approaches. In: Robotics and Computer-Integrated Manufacturing, Vol. 27, No. 1, pp.1-12.

[2] HUI WANG, YIMING (KEVIN) RONG, HUA LI, PRICE SHAUN (2010). Computer aided fixture design: Recent research and trends. In: Computer-Aided Design, Vol. 42, No. 12, pp.1085-1094.

[3] HEIDAR HASHEMI, AWALUDDIN MOHAMED SHAHAROUN, IZMAN S. (2014). Fixture Designers Guidance: A Review of Recent Advanced Approaches. In: Jordan Journal of Mechanical and Industrial Engineering, Vol. 8 No. 6, pp.377-384.

[4] WANG ZHUN (2014). Studying the design and verification of 5-axis NC program under the manufacturing system. In: Jordan Journal of Mechanical and Industrial Engineering, Vol. 8, No. 3, pp.137-141.

[5] KUANG-HUA CHANG (2014). Design Theory and Methods using CAD/CAE: The Computer Aided Engineering Design Series, Academic Press, ISBN: 978-0123985125.

[6] KUANG-HUA CHANG (2015). e-Design: Computer-Aided Engineering Design, 1st Edition, Academic Press, ISBN: $978-0123820389$.

[7] FARHAD AMERI, DEBA DUTTA (2005). Product Lifecycle Management- Closing the Knowledge Loops. In: Computer-Aided Design \& Applications, Vol. 2, No. 5, pp.577-590.

[8] FRANCESCO RICCI, JOEL SAUZA BEDOLLA, JAVIER MARTINEZ GOMEZ, PAOLO CHIABERT (2014). PMI: a PLM Approach for the Management of Geometrical and Dimensional Controls in Modern Industries. In: Computer-Aided Design \& Applications, Vol. 11, No. 1(Supplement), S36-S43.

[9] MARTIN EIGNER, FABRICE MOGO NEM (2010). On the Development of New Modeling Concepts for Product Lifecycle Management in Engineering Enterprises. In: Computer-Aided Design \& Applications, Vol. 7, No. 2, pp.203-212.

[10] WANG ZHUN (2014). Research to the overall design of 4-axis VMC based on CAD and NC MFG verification. In: Applied Mechanics and Materials, Vol. 607, No. 2014, pp.577-580.

[11] BALACHANDRAN, V. (2015). Design of Jigs, Fixtures and Press Tools, Notion Press, ISBN: 978-9352060306.

[12] AIGBEDO, H. (2009). On bills of materials structure and optimum product-level smoothing of parts usage in JIT assembly systems. In: International Journal of Systems Science, Vol. 40, No. 8, pp.787-798.

[13] LINDA L. ZHANG, ELISE VAREILLES, MICHEL ALDANONDO (2013). Generic bill of functions, materials, and operations for SAP2 configuration. In: International Journal of Production Research, Vol. 51, No. 2, pp.465478.

[14] LI, J., W. MA, Y. RONG (1999). Fixturing surface accessibility analysis for automated fixturing design. In: International Journal of Production Research, Vol. 37, No. 13, pp.2997-3016.

[15] KYNCL, J. (2016). Digital Factory Simulation Tools. In: MANUFACTURING TECHNOLOGY. Vol. 16, No. 2, pp. 371-375. 
[16] ANJIANG CAI,LIANG QIANG,SHIHONG GUO,ZHAOYANG DONG (2012). The Five-Axis NC Machining Simulation and Optimization. In: Advances in Mechanical and Electronic, pp. 395-401. Engineering Publisher Springer Berlin Heidelberg, ISBN: 978-3-642-31506-0.

[17] WANG ZHUN (2015). A NEW METHOD OF MACHINING THE COUNTERSINKS DISTRIBUTED IN MULTI-DIRECTIONAL BACK-FACES. In: ACADEMIC JOURNAL OF MANUFACTURING ENGINEERING. Vol. 13, No. 4, pp.75-80.

[18] D. F. XU, Y. CHEN, W. L. CAI, H. P. XIANG (2012). Application of NC Machining Simulation System Based on VERICUT. In: Advanced Materials Research, Vol. 548, pp. 484-488.

Copyright (C) 2017. Published by Manufacturing Technology. All rights reserved. 